УДК 791.43/.45:74.01.09

DOI https://doi.org/10.24919/2308-4863/34-1-3

Олександр БЕРЛАЧ, orcid.org/0000-0002-8567-3268 кандидат архітектури,

доиент кафедри образотворчого мистеитва і дизайну Волинського національного університету імені Лесі Українки (Луиьк, Україна) sasha.berlach@gmail.com

Оксана ЛЕСИК-БОНДАРУК, orcid.org/000-0003-1460-2101 кандидат архітектури, доиент кафедри образотворчого мистеитва і дизайну Волинського національного університету імені Лесі Українки (Луцьк, Украӥна) O_Bondaruk@ukr.net

\title{
ХУДОЖНЬО-ТЕХНОЛОГІЧНІ ОСОБЛИВОСТІ СТВОРЕННЯ АНІМАЦІЙНИХ ПЕРСОНАЖІВ АВТОРСЬКОЇ ВЕКТОРНОЇ АНІМАЦІї
}

Статтю присвячено проблемі створення якісних анімаційних персонажів дитячої мультиплікації засобами мультимедійного дизайну. У нашому сьогоденні сучасне екранне середовище, щзо оточує людину, представляє складний інформаційний простір, наповнений візуальними образами, які не завжди є художніми. Зовнішня привабливість персонажів анімації має поєднуватися з навчально-пізнавальним призначенням мультфільму, глибиною та креативністю ідеї, сиенарію. Така анімація сприяє пізнанню та розвитку дітей, стимулює розумову активність.

Проблема полягає у відносно низькій якості екранних образів. Виготовлення навіть короткометражної анімачії є трудомістким та довготривалим процесом, який потребує не лише художніх, а й технічних навичок, креативності мислення. Окрім цьього, якісна анімачія є досить вартісною, і тому глядач з екрану бачить технічні, а не мистецькі мультфільми, щзо базуються на екщені та спецефектах, при изьому режисери анімації не завжди дотримуються естетичних норм та правил створення персонажів. Анімаційний фільм має стимулювати пізнавальний інтерес, допитливість глядача. Професійно виконані анімаційні образи є пізнавальними для дитини, насичують ї̈ не лише емочійно, а й морально, інтелектуально.

Анімація є екранним синтетичним мистецтвом, яке поєднує в собі можливості впливу на глядача через актуальну ідею, художньо-досконалу візуальну подачу, озвучення. Вирішення завдань такого роду стає можливим иляхом комплексного вивчення технологій даного мистецтва, постійного творчого пошуку та експериментів зі створення авторської векторної анімації. Векторна анімаџія активно впроваджується в ігрове кіно, рекламу. Трансформується ї̈ художня мова, активно реалізуються нові технічні можливості. У изому контексті особливої актуальності набуває проблема оволодіння аніматорами-початківиями художньо-технологічними основами векторної анімації, щчо дає широкі науково обтрунтовані можливості в реалізаџії креативних ідей. щиниі.

Простежено проблематику якості анімаційних персонажів, яка, на нашу думку, лежить у мистецькій пло-

Ключові слова: векторна анімація, мультиплікація, персонажі, екшени, програма, Anіте Studio Pro 9.5, мультимедійний дизайн. 


\author{
Oleksandr BERLACH, \\ orcid.org/0000-0002-8567-3268 \\ Candidate of Architecture, \\ Associate Professor at the Department of Fine Arts and Design \\ Lesya Ukrainka Volyn National University \\ (Lutsk,Ukraine)sasha.berlach@gmail.com
}

Oksana LESYK-BONDARUK, orcid.org/000-0003-1460-2101

Candidate of Architecture,

Associate Professor at the Department of Fine Arts and Design

Lesya Ukrainka Volyn National University

(Lutsk,Ukraine) O_Bondaruk@ukr.net

The article is devoted to the problem of creating high-quality animated characters of children's animation by means of multimedia design. Today, the modern screen environment that surrounds a person is a complex information space filled with visual images that are not always artistic. The external attractiveness of the animation characters must be combined with the educational and cognitive purpose of the cartoon, the depth and creativity of the idea, the script. Such animation promotes cognition and development of children, stimulates mental activity.

The problem is the relatively low quality of screen images. Making even a short animation is a laborious and lengthy process that requires not only artistic but also technical skills, creativity, thinking. In addition, high-quality animation is quite expensive, and therefore the viewer sees from the screen technical, not artistic cartoons based on action and special effects, while animation directors do not always follow the aesthetic norms and rules of character creation. The animated film should stimulate cognitive interest, curiosity of the spectator. Professionally made animated images are informative for the child, saturate it not only emotionally, but also morally, intellectually.

Animation is a screen synthetic art, which combines the possibilities of influencing the viewer through a topical idea, artistically perfect visual presentation, sound. Solving problems of this kind becomes possible through a comprehensive study of the technologies of this art, constant creative search and experiments to create author's vector animation. Vector animation is actively implemented in feature films, advertising. Its artistic language is being transformed, new technical possibilities are being actively implemented. In this context, the problem of mastering by beginner animators artistic and technological bases of vector animation becomes especially relevant, which gives a wide range of scientifically substantiated opportunities in realization of creative ideas.

The problem of the quality of animated characters, which in our opinion, lies in the artistic plane, is traced.

Key words: vector animation, animation, characters, action, program, Anime Studio Pro 9.5, multimedia design.

Постановка проблеми. Серед різноманіття анімаційних технологій векторна анімація посідає чільне місце в мультимедійному дизайні. Вона сприяє розвитку пізнавального інтересу, стимулює розумову активність, на відміну від художньо і технічно недосконалої анімації. Виготовлення навіть короткометражної анімації є трудомістким та довготривалим процесом, який потребує не лише художніх, а й технічних навичок, креативності мислення.

Українська анімація має приклади вдалого використання художньо-технічного інструментарію векторної технології, зокрема «Шерлок Холмс та чорні чоловічки» (2012, реж. О. Бубнова), «Птахи» (2013, реж. І. Смірнова), «Маленький великий пес» (Укранімафільм, 2008), «Викрадена принцеса: Руслан і Людмила» (Animagrad (Київ), 2018), в яких присутні художні прийоми діснеївської школи (фактурність, пластика персонажів), повнометражний мультфільм «Мавка» (Animagrad (Київ), 2019).
Незважаючинаширокіможливостікомп'ютерної анімації, технічні засоби не можуть знівелювати художність іiі засобів, залишаючи векторні мультиплікаційні фільми авторським шедевром.

Українські науковці вважають, що необхідно розширювати художньо-образну мову анімації. Це можливо зробити шляхом подальших наукових розвідок, розроблення відповідних методик, підготовки аніматорів, відкриваючи дитячі анімаційні студії, заохочуючи до створення високохудожнього мультимедійного продукту. Проте вищезгадані питання в наукових колах фахівців недостатньо вивчені, а тому актуальні для українського мистецтва в цілому.

Аналіз досліджень. Для аналізу тематики дослідження важливо з'ясувати історію появи комп'ютерної анімації (векторної в тому числі), а також тематичну спрямованість досліджень науковців.

Поява та розвиток мистецтва анімації пов'язані 3 винайденням фотоапарата, кінематографа, целу- 
лоїду, пізніше - комп’ютера. Історія анімаційного мистецтва, а також технології класичної анімації досліджена в працях багатьох науковців, зокрема: П. Блера, Н. Беркової, С. Асеніна, І. Вано, М. Сітцевої, Б. Крижанівського, А. Колодка, О. Шупик, О. Лагутенко (Мурашко, 2017: 3).

Мистецтво комп'ютерної анімації досліджували М. Саймон, Л. Іволга, Н. Кривуля, К. Разлогов, М. Безрідний, О. Мацан, Н. Скляренко, О. Орлов, Л. Сухорукова. У своїх працях вони описують технологію та основні закономірності створення комп'ютерної анімації. Питання створення художнього образу та його впливу на глядачів аналізують 3. Алфьорова, М. Мурашко та ін. Психологічні аспекти анімації розкрито в дослідженнях Є. Сивоконя, М. Сітцевої, Б. Крижанівського та ін. (Мурашко, 2017: 2).

Проте проблема взаємодії художньої творчості та комп'ютерних технологій залишається малодослідженою ділянкою мистецтвознавства, також актуальним залишається популяризація питання щодо створення авторських анімаційних студій.

Комп'ютерна анімація тісно пов'язана з появою і розвитком спеціалізованих графічних програмних пакетів. Першим кроком у технології візуальних ефектів стала створена в 1961 році Айваном Сазерлендом система Sketchpad, яка започаткувала еру комп'ютерної графіки. У 1986 році фірма AT\&T випустила перший пакет для роботи 3 анімацією на персональних комп'ютерах (TOPAS). У 1990 році фірма AutoDesk розпочала продаж продукту 3D Studio. У 1997 році компанія Macromedia придбала у компанії FutureWare невелику графічну програму для «веб», 3 якої була започаткована загальновідома нині програма комп'ютерної анімації Adobe Flash. У 1998 році розпочався випуск додатка Мау (Іволга, 2014: 6).

Першу українську мистецьку анімацію «Малює EОМ. Азбучна істина» із вставками комп'ютерної графіки виготовили студенти на кіностудії Харківського політехнічного інституту в 1975 році (Мурашко, 2017: 8).

В Україні комп'ютерна векторна анімація набула поширення наприкінці 1990-х років («Укранімафільм», студія «Борисфен-С»). Художники-аніматори «Укранімафільму» для створення мультфільмів використовували останні розробки в технології комп'ютерної анімації. Студія перейшла на сучасні формати, щоб мати можливість виходу на європейський ринок. У технології комп'ютерної анімації було створено мультфільми: «Літачок Ліп» (2000, режисер Наталя Марченкова), «Ключ» (режисер О. Педан, 2004), «Калейдоскоп» (режисер Володимир Михайлов
2006). Комп'ютер став необхідним інструментом, який замінив технологію целулоїдної перекладки, спростив покадрову класичну технологію, розширив технологічний спектр (векторна, флеш, 3D, стоп-моушен, ключових кадрів та ін.), урізноманітнив і певною мірою спростив деякі етапи створення мультфільму.

Згодом з'явилися студії, які почали виготовляти класичну та комп'ютерну короткометражну та повнометражну анімацію, кліпи, рекламу («Lisenbart animation studio» (Київ), «Тунгуру» (Донецьк), «Одеська Студія Мультиплікації» (Одеса), «Сахалтуєв-Продакшн» (Київ) та ін. Ці компанії працюють переважно в технологіях 2D-графіки 3 використанням таких програм, як Adobe Flash, Adobe After Effects, Anime Studio Pro (Moho), Toon Boom studio (Іволга, 2014: 9).

У 2012-2013-х роках українська анімація розвивається в технології 3D («Ескімоска», студія ім. А. А. Ханжонкова; «Казкова Русь», студія «Animagrad»; «Микита Кожум'яка і вогненна квітка», студія «Панама Гран Прі»; «Пригоди кота Викрутаса», «Казковий патруль», «Легенди України», «Духовне намисто», «Історія України в постатях», студія «Арт-відео» Львів).

На думку Л. В. Іволги, сьогодні рівень українських анімаційних проектів програє (якістю та естетичним рівнем) сучасним світовим тенденціям розвитку цього виду мистецтва (Іволга, 2014: 7). Проблема полягає у відсутності фінансування та масовізації культури. Ці фактори негативно позначилися на створенні анімаційними студіями креативної авторської анімації.

Сьогодні студія «Укранімафільм» випускає мало мультфільмів, їхня якість знизилася через перехід на комп'ютерні технології (добір занадто яскравих кольорів, «роботоподібність» рухів, утрата художності контуру, відсутність єдиної стилістики). Це сталося через відсутність навичок в аніматорів мистецької бази, що призвело до низької якості моделювання персонажів мультфільмів, непродуманості та неправдоподібності рухів. Як зазначає Л. Іволга у своїй праці «Взаємодія комп'ютерних технологій та художньої творчості в українській аніматографії», зазначена тенденція є характерною для всіх державних анімаційних студій, які на сучасному етапі значно поступаються в мистецтві анімації приватним. Значна частина українських аніматорів не використовує реальні можливості технології векторної анімації, яка $є$ близькою та зрозумілою дітям завдяки відповідності художніх засобів віковим особливостям сприймання (Іволга, 2014: 16). 
Проте проблема створення анімаційних персонажів авторської векторної анімації для конкурентної спроможності мультиплікації на європейських ринках залишається відкритою, тому наше дослідження покликане стимулювати інтерес до вивчення мистецьких та інформаційних технологій, розвитку креативності в мультимедійній дизайнерській освіті.

Мета статті - провести аналіз наукового стану розвитку комп'ютерної анімації в Україні, а також визначити художньо-технологічні особливості створення анімаційних персонажів авторської векторної анімації.

Виклад основного матеріалу. Одним із популярних видів кіномистецтва $\epsilon$ анімація (з лат. anima - душа і похідного фp. animation - оживлення), мультиплікація (з лат. multiplicatio - розмноження, збільшення, зростання). Анімація грунтується на принципі діяльності зорових аналізаторів - інертності зорового сприйняття. Різниця між анімацією і відео полягає в тому, що відео використовує безупинний рух і розбиває його на множину дискретних кадрів, а анімація використовує множину незалежних малюнків або графічних файлів, що виводяться в певній послідовності для створення ілюзії безупинного руху.

Векторна анімація - різновид мистецтва двовимірної комп'ютерної анімації, виконаної в програмі, призначеної для роботи з векторними зображеннями - ілюстраціями (Зеньковський, 2010: 6) в нашому випадку це Anime Studio Pro 9.5.

У векторній графіці базовим елементом технології побудови зображення є лінія, яка описується математично як єдиний об'єкт, тому обсяг даних для відображення об'єкта засобами векторної графіки суттєво менший, ніж у растровій графіці, де елементом побудови зображення $є$ точка - піксель. Лінія характеризується формою, товщиною, кольором, типом. Замкнуті лінії мають властивість заповнення простору, що ними охоплюються, іншими об'єктами або кольором створюється форма. Найпростішими векторними лініями є пряма, відрізок, криві, криві Безьє (засновані на використанні пари дотичних, проведених до відрізка лінії в іiї кінцях, кути нахилу і довжина яких впливають на форму лініі). Векторна графіка зручна для зберігання й обробки зображень, що складаються 3 ліній або можуть бути розкладені на прості геометричні об'єкти. Векторні дані легко масштабувати та виконувати над ними інші перетворення (наприклад, повертання зображення, додавання, видалення або зміну окремих елементів зображення). Поряд із цим векторні файли важко застосувати для зберігання складних фото- реалістичних зображень. Векторні дані краще відображаються на векторних пристроях виводу (плотерах, дисплеях із довільним скануванням). Ефективно векторну графіку можна відобразити тільки на растрових дисплеях із високою роздільною здатністю (Свсєєв, 2014: 76).

У мультимедійному дизайні векторна анімація дає широкий спектр можливостей для творчості, в тому числі масштабування персонажів, предметів середовища, стискання у два, три рази без втрати якості. Це ефективна технологія, яка дозволяє створювати файли відносно невеликих розмірів навіть під час роботи зі складними зображеннями (Сухорукова, 2012: 144).

Ми вважаємо, що векторна анімація як технологія $є$ дієвою лише в поєднанні з технологією класичної анімації, а також растровою графікою. Для створення мистецького мультфільму початківцю потрібно оволодіти різними технологіями анімації та навчитися доцільно їх поєднувати. Мистецька векторна анімація має відмінності від техніки створення векторних комп'ютерних анімаційних зображень (які створюються в навчальних закладах на уроках інформатики). Вона має продуманий авторський сюжет, сценарій, персонажі детально промальовані та змодельовані в різних ракурсах, їм притаманні емоційність та характер, передбачає велику кількість замальовок та ескізів, використовує принципи Уолта Діснея, закони та прийоми композиції, геометричні примітиви виконують функції художніх засобів (зміна товщини контурів, використання прозорості, тіней, законів перспективи, плановість). Технологію анімації 3 точки зору інформатики розглядають дуже спрощено, спираючись лише на процес ії створення, проте досить примітивно: 1) розміщення об'єктів у заданих точках екрана; 2) відображення об'єктів упродовж визначеного проміжку часу; 3) знищення об'єктів. Ні про яке мистецтво тут і не йдеться - це технічне ремесло (Сухорукова, 2011: 142).

Саме тому ми розглядаємо векторну технологію анімації як частину інструментарію анімаційного мистецтва під час створення анімаційних персонажів майбутнього мультиплікаційного фільму. На нашу думку, вона є складником мультимедійного дизайну, який насамперед грунтується на мистецтві, а інформаційні технології та програми лише полегшують працю художнику-аніматору, розширюють можливості творчої самореалізації.

Технології змінюються, і векторна двовимірна анімація є доступною для творчості, а також дає необмежені можливості в плавності рухів, передачі емоцій, полегшує ліпсинг анімаційних пер- 
сонажів. Окрім цього, авторські короткометражні векторні анімаційні фільми вирізняються креативними ідеями й технічними вдосконаленнями, адже один і той самий анімаційний рух персонажа можна досягнути багатьма технічними та художніми прийомами (Мурашко, 2017: 13).

Векторна технологія, на відміну від покадрової анімації, дозволяє ефективніше працювати над композицією малюнка, домагатися гармонійного художнього образу. Технологія полягає у створенні та моделюванні анімаційних персонажів, наділення їх емоціями та харизмою через написання екшенів для очей, зіниць, губ, брів, кісток рук та ніг. В анімаційному мистецтві персонаж - вигадана особа, наділена певним характером і унікальними зовнішніми даними (Мурашко, 2017: 11).

Створення художніх образів мультфільму включає ряд технічних особливостей: складання багатошарової структури персонажа, використання векторних масок, багатоплановість тощо (Іволга, 2014: 13). Ряд традиційних художніх та технічних прийомів використовуються впродовж усього мультфільму, а спеціальні використовуються в окремих випадках. Саме тому ми звертаємо увагу на аналіз використання найтиповіших прийомів, які $\epsilon$ важливими в процесі векторної анімації. Малюнок персонажів здійснюється у трьох положеннях (ракурсах) - анфас, три четверті й профіль. Це необхідно для цілісного уявлення про створюваний персонаж.

Художньо-технологічний процес створення авторського анімаційного фільму включає такі етапи: вибір концепції та створення сценарію (фантазування і написання); створення головних героїв (виконання замальовок, ескізів персонажів, вибір найбільш вдалого художнього образу, виконання персонажів у різних положеннях (ракурcax), розбивка сценарію на епізоди (сцени); малювання фонів, моделювання персонажів у програмі для векторної анімації (створення багатошарових моделей, наділення персонажу скелетом); накладення звуку, назви та титрів.

Лінійний ескіз персонажів створюється за допомогою анімаційної сітки. Моделювання персонажів - важливий етап створення анімації, від якого залежить правдоподібність рухів, точність з'єднань елементів, художність образу. Моделювання у векторній технології виконується технікою перекладки. Перекладка (англ. Cut-out) полягає в розбитті плоского (двохвимірного) персонажа на окремі частини (шари), які можуть незалежно рухатися одна відносно одної. Векторна перекладка в анімації - одна 3 універсальних технологій, яка дозволяє створити цікаві візуальні ефекти, передати художній задум. Перекладна анімація $є$ наближеною 3 мистецтвом графіки та живопису, а отже, використовує подібні художні прийоми та засоби (Мурашко, 2014: 9).

Розглянемо технологію на прикладі моделювання персонажа. Для однієї моделі створюємо певну кількість векторних шарів (шари голови, очей, губ містять у собі підшари). Кожен із шарів $€$ замкнутим контуром певної частини персонажа 3 виконаною заливкою (кожен контур складається 3 мінімальної, але достатньої кількості характерних точок, які визначають форму) (Александр Птичкин, 2018).

Кожен із трьох ракурсів - нова модель персонажа, яка створюється спочатку. Для моделювання деталей обличчя персонажа застосовуємо векторні маски (які не дозволяють під час анімації зіниць з'являтися за межами внутрішнього контуру розрізу очей).

У технології можливе і створення кількох форм у межах одного шару (наприклад ноги і руки персонажа можуть бути в одному шарі з тулубом), проте подальша анімація такої моделі буде неякісною. Основні емоції анімаційного персонажа засновані на русі частин обличчя (очі, брови, кінчики рота), тому важливо створити логічну структуру їх моделі, що дасть можливість анімувати кожну деталь (полиск на очах, форма брів, кутики рота).

Далі модель персонажа розбирається на векторні деталі (шари), які розміщуються на певній відстані від тулуба. Створюється кістковий шар, у структуру якого переміщуються всі векторні шари моделі. У кожну частину тіла, яка має анімуватися, вставляються кістки скелету. Розмір векторних кісток відповідає анатомічним особливостям будови тіла людини, що під час анімації дає можливість руху (необхідно враховувати положення суглобів). На даному етапі важливо розпочинати від тазового поясу, в який монтується головна кістка - забезпечує рух персонажа в композиції кадру. Між кістками налагоджується зв'язок, коли переміщуємо, наприклад, шию, за нею рухається голова. Також важливо налаштувати силу впливу кісток (розмір області впливу відповідає розмірам форми у векторному шарі), щоб після складання деталей моделі в персонажа одна й та ж кістка не переміщувала сусідні вектори. Після встановлення зв'язків, сили та області впливу кісток, деталі моделі збираються в цілісну структуру (Птичкин, 2018).

Для деталей, наприклад, кінчиків волосся, які мають рухатися під час переміщення тулуба, створюємо кістки, які наділили динамічними якостями. Даний технічний прийом є доцільним, 
адже робить персонаж природнішим, а покадрова анімація деталей способом переміщення точок вектору є довготривалою. Під час створення руху персонажа використовуємо кілька анімаційних технологій, які полягають у переміщенні шарів, трансформації контуру векторів, покадровому малюванні, зміні властивостей шару (прозорість, видимість, та ін.), створенні циклів, проте технологія ключових кадрів $є$ домінуючою. Вона полягає у зміні положення кісток персонажу протягом зміни кадрів на шкалі часу (таймлайні). Особливість анімації ходи полягає в тому, що рух персонажа створюється на одному місці (за принципом тренажера бігової доріжки) з використанням шкали в нижній частині екрану (може бути умовною, в залежності від того, який характер ходи потрібно створити).

У композиції кадру найбільш важливим є розташування елементів, які створюють гармонію i врівноваженість композиції. Таке зображення досягається особливим зіставленням пропорції предметів, кольором і тоном, співвідношенням світла й тіні. Гармонійно створений кадр має композицію, в якій немає випадкових візуальних елементів, викликає позитивні емоції глядача. Для вдалої композиції кадру характерна стилістична єдність художньо-графічних засобів і чітка структура організації екранного простору.

На відміну від площинних видів мистецтва, анімації властива зміна композиції в часі, що $\epsilon$ перевагою і проблемою водночас, оскільки художнику часто потрібно продумувати декілька композицій у межах одного епізоду, а для втілення цілісної ідеї, навіть кількахвилинного мультфільму, кількість продуманих композицій іде на десятки, а то й сотні. М. В. Мурашко подає структуру анімаційного кадру як сукупність засобів організації (крапка, лінія, пляма, площина, простір), засобів гармонізації (метр-ритм, симетрія-асиметрія, статика-динаміка, контраст-нюанс) й засобів вираження (форма, колір, фактура), що веде до дотримання принципів (супідрядність, повторення, розмірність, рівновага, єдність), які забезпечують цілісну гармонійну композицію кадру i, як наслідок, композиційну завершеність мультфільму. Кожна сцена роликів будується за цими законами для цілісного й гармонійного поєднання в композиції різних елементів (Мурашко, 2017: 15).

На окрему увагу заслуговують особливості функції ліпсингу персонажів авторської векторної анімації. Анімацію рота кожного персонажу реалізуємо через функцію ліпсингу та створення шару Перемикач (Swich), який включав у себе набір форм рота під час розмови. Упродовж роз- мови губи і язик людини видають фонеми, які можуть виражатися у своєрідний «анімаційний алфавіт» - віземи (Птичкин, 2018). Наприклад, під час створення ліпсингу персонажів дотримуємось таких візем. Малюємо потрібну кількість положень рота і язика для кожної фонеми (кожен рот $€$ новим груповим шаром, який складається із таких вкладених шарів: губи, зуби, язик і ротова порожнина). Шар підписуємо відповідно до звуків, які позначав (наприклад, А-Е-Я, О-У, І-И-Й, Л, Д-Т-З-С, В-Ф, Д-Т-З-С, П-Б-М, закритий рот). Після вставляння звукової доріжки у сцену, в програмі Anime Studio відбувається переключення шарів-візем відповідно до аудіодоріжки. Особливість ліпсингу полягає у відображенні віземи на 2-4 кадри раніше відповідної фонеми. Даний прийом використовується в анімації задля якісної синхронізації і запобігання відставання анімації рота від голосу персонажа. Переключення шарів візем може виконуватися автоматично програмою, якщо розмістити шари в послідовності від закритого до найбільш відкритого рота, проте якість такого ліпсингу є низькою. Виникає збій синхронності, тому ми радимо використовувати ручне переключення шарів. Додавання синхронізації артикуляції губ персонажа вручну є довшим і складнішим процесом, проте якість у рази краща (Сухорукова, 2011: 142).

Отже, ліпсинг $є$ досить складним етапом у створенні мультфільму, який потребує художніх навичок у зображенні візем, а також творчих підходів у створенні чітких перебільшених художніх образів, знання анатомії.

Для створення якісного мультимедійного продукту важливо вивчити особливості руху камери під час створення сцен, що у своїй більшості зумовлено художнім задумом та сценарієм.

Інструменти програми Anime Syudio Pro 9.5 мають свої особливості. Рух камери в програмі здійснюється чотирма інструментами, які забезпечують різне переміщення. Лінійне переміщення (камера рухається в площині екрану відносно координат XY: вправо, вліво, вгору, вниз, змінивши точку, з якої спостерігається сцена). Натиснувши клавішу $<$ Alt $>$, можна переміщатися і по напрямку осі Z (вглиб екрану). Другий тип переміщення - зумування камери (збільшення і зменшення зображення) - дозволяє наближати або віддаляти об'єкти сцени. Таке переміщення створює ілюзію наближення чи віддалення від об'єктів сцени. Поворот камери обертає сцену навколо іiі центру у вертикальній площині XY. Панорамна камера імітує ефект зображення персонажа, який стоїть на місці й оглядається, повертаючи голову. 
У технологічному плані створення руху камери грунтується на створенні ключових кадрів (ключів) на часовій шкалі (таймлайні).

Описані художньо-технологічні особливості створення анімаційних персонажів авторської векторної анімації є оптимальними для початківця, який прагне створити мистецький продукт.

Висновки. 3'ясовано, що анімаційне мистецтво $\epsilon$ видом кінематографу, а векторна мультиплікація - різновидом двовимірної комп'ютерної графіки, заснованої на технології побудови зображення на основі геометричних примітивів. Принцип створення, екранного відображення цього мистецтва грунтується на інертності зоро- вого сприйняття (перцепції). Анімація твориться шляхом виводу на екран видозмінених зображень (кадрів), що сприймається глядачем як ілюзія руху. Особливості технології створення авторських анімаційних персонажів полягають у розробці та моделюванні багатошарової структури персонажів технікою перекладки, наділення їх емоціями та харизмою через написання екшенів, використанні методу ключових кадрів, векторних масок, мальованих фонів, зміною властивостей шарів (прозорість, видимість та ін.), плановості та руху камери (виконує функцію акцентування уваги та поступового розкриття сюжету), накладенні звуку, виконанні текстового оформлення.

\section{СПИСОК ВИКОРИСТАНИХ ДЖЕРЕЛ}

1. Птичкин A. Mult-uroki. Уроки Anime Studio Pro 11 (Moho). 2018. URL: https://mult-uroki.ru (дата звернення: 11.10.2020).

2. Євсєєв О. С. Комп'ютерна анімація : навчальний посібник для студентів напряму підготовки 6.051501 «Видавничо-поліграфічна справа». Харків : ХНЕУ ім. С. Кузнеця, 2014.152 с.

3. Зеньковский В. А. Anime Studio Pro 5.6/6.0. Создание анимационных фильмов на примерах. Санкт-Петербург, 2010. 592 c.

4. Іволга Л. В. Історично-культурні передумови розвитку української анімації та естетичні критерії художнього пошуку. URL: http://nauka.zinet.info/21/ivolga.php

5. Іволга Л. В. Взаємодія комп'ютерних технологій та художньої творчості в українській аніматографії. Теорія та практика дизайну : зб. наук. праць. Київ : «Комп’ютерпрес». 2014. Випуск 5. С. 45-67.

6. Мурашко М. В. Проектно-художній інструментарій моушн-дизайну (на прикладі рекламного ролика) : автореф. дис. ... на здобуття наук. ступеня канд. мистецтвознавства : 17.00.07 «Дизайн» ; ХДАДМ. Харків, 2017. 20 с.

7. Сивоконь С. Мультфільм «на замовлення. Свій півстолітній ювілей українська анімація зустріла тотальним скороченням штатів. URL: https://zn.ua/ukr/article/print/ART/multfilm na zamovlennya.html

8. Сітцева М. Психологічні особливості мультфільмів для дітей. Вісник інституту розвитку дитини. Серія: філософія, педагогіка, психологія : зб. наук. пр. ; Нац. пед. у-ту ім. Драгоманова. Ін.- т розв. дитини. Київ : В-во НПУ ім. В. Драгоманова, 2012. Випуск 23. С. 155-158.

9. Сухорукова Л. А. Візуально-звукова гармонія у творчості дизайнера мультимедіа. Матеріально-художня культура: проблеми теорї та практики : зб. ст. всеукр. наук.-практ. конф. за підсумками роботи у 2010-2011 н. р. Харків : ХДАДМ, 2011. С. 140-143.

10. Сухорукова Л. А. Види і класифікація технологічних засобів створення мультимедійного продукту. Традиціi та новації у вищчій архітектурно-художній освіті : зб. наук. праць. Харків : ХДАДМ, 2012. Випуск 3. С. $142-146$.

\section{REFERENCES}

1. Aleksandr Ptychkyn. Mult-uroki. Uroky Anime Studio Pro 11 (Moho) [Mult-lessons. Lessons from Anime Studio Pro 11 (Moho)]. 2018 : veb-sait. URL: https://mult-uroki.ru (data zvernennia 11. 10. 2020) [in Russian].

2. Ievsieiev O. S. Kompiuterna animatsiia : navchalnyi posibnyk dlia studentiv napriamu pidhotovky 6.051501 "Vydavnycho-polihrafichna sprava" [Computer animation: textbook for students in the direction of training 6.051501 "Publishing and printing business"]. Kharkiv : KhNEU im. S. Kuznetsia, 2014.152 p. [in Ukrainian].

3. Zenkovskyi V. A. Anime Studio Pro 5.6/6.0. Sozdanye anymatsyonnukh fylmov na prymerakh. [Anime Studio Pro 5.6 / 6.0. Creating animated films on examples]. SPb, 2010. 592 p. [in Russian].

4. Ivolha L. V. «Istorychno-kulturni peredumovy rozvytku ukrainskoi animatsii ta estetychni kryterii khudozhnoho poshuku». ["Historical and cultural preconditions for the development of Ukrainian animation and aesthetic criteria of artistic search"]. URL: http://nauka.zinet.info/21/ivolga.php [in Ukrainian].

5. Ivolha L. V. Vzaiemodiia kompiuternykh tekhnolohii ta khudozhnoi tvorchosti v ukrainskii animatohrafii. [ Interaction of computer technologies and artistic creativity in Ukrainian animation]. Theory and practice of design: coll. Science. wash. K. : «Kompiuterpres». 2014. Vypusk 5. Pp. 45-67 [in Ukrainian].

6. Murashko M. V. Proektno-khudozhnii instrumentarii moushn-dyzainu (na prykladi reklamnoho rolyka) [Design and artistic tools of motion design (on the example of a commercial] [Text]: author's ref. dis. for science. degree of Cand. art history. Special. 17.00.07 "Design". KhDADM. Kharkiv, 2017. 20 p [in Ukrainian].

7. Syvokon Ye. Multfilm «na zamovlennia». Svii pivstolitnii yuvilei ukrainska animatsiia zustrila totalnym skorochenniam shtativ. [Cartoon "to order". Ukrainian animation celebrated its half-century anniversary with a total reduction of staff]. Recovered from https://zn.ua/ukr/article/print/ART/multfilm_na_zamovlennya.html [in Ukrainian].

8. Sittseva M. Psykholohichni osoblyvosti multfilmiv dlia ditei. [Psychological features of cartoons for children]. Bulletin of the Institute of Child Development. Series: philosophy, pedagogy, psychology: coll. Science. etc. / Nat. ped. in 
Берлач О., Аесик-Бондарук О. Художньо-технологічні особливості ...

them. Драгоманова. In.-t development. children. Kyiv: V-vo NPU im. V. Drahomanova, 2012. Vypusk 23. Pp. 155-158 [in Ukrainian].

9. Sukhorukova L. A. Vizualno-zvukova harmoniia u tvorchosti dyzainera multymedia. [Visual and sound harmony in the work of a multimedia designer]. Material and artistic culture: problems of theory and practice: coll. Art. All-Ukrainian Science.-practice. conf. following the results of work in 2010-2011 p. Kharkiv: KhDADM, 2011. Pp. 140-143 [in Ukrainian].

10. Sukhorukova L. A. Vydy i klasyfikatsiia tekhnolohichnykh zasobiv stvorennia multymediinoho produktu. [Types and classification of technological means of creating a multimedia product]. Traditions and innovations in higher architectural and artistic education: coll. Science. Wash. Kharkiv: KhDADM, 2012. Vypusk 3. Pp. 142-146 [in Ukrainian]. 